American Journal of Agricultural and Biological Sciences 5 (4): 422-429, 2010

ISSN 1557-4989

(C) 2010 Science Publications

\title{
Glomalin Production and Microbial Activity in Soils Impacted by Gypsum Mining in a Brazilian Semiarid Area
}

\author{
${ }^{1}$ Adália Cavalcanti do Espírito Santo Mergulhão, ${ }^{1}$ Helio Almeida Burity, \\ ${ }^{2}$ Fábio Sérgio Barbosa da Silva, ${ }^{3}$ Sônia Valéria Pereira and ${ }^{4}$ Leonor Costa Maia \\ ${ }^{1}$ Agronomic Institute of Pernambuco-IPA, Genomic Laboratory, \\ General San Martin Avenue 1371, Bonji 50761-000, P. O. Box 1022, Recife, PE, Brazil \\ ${ }^{2}$ University of Pernambuco, Petrolina's College for Teacher Formation, FFPP, PE, Brazil \\ ${ }^{3}$ Technological Institute of Pernambuco-ITEP, Laboratory of Environmental Biotechnology, PE, Brazil \\ ${ }^{4}$ Pernambuco Federal University-UFPE, Mycorrhiza Laboratory, 50670-420, Recife, PE, Brazil
}

\begin{abstract}
Problem statement: Mining activities involve the removal of the vegetal cover and the soil organic layer, causing a severe environmental impact. In Northeast Brazil, $40 \%$ of the world's crude gypsum is found in a semiarid area, making this region responsible for $95 \%$ of the gypsum demand in the national market. Although economically important, this activity is harmful to the environment. Studies of soil microbiological and biochemical attributes can help in the identification of the limitations of impacted ecosystems, providing data to define strategies for sustainability of such environments. Approach: To evaluate and compare the biological state of preserved and mining degraded semiarid soils, a native preserved area and areas impacted by gypsum mining were selected at the Araripina Experimental Station, located in the semiarid region of Pernambuco State, Northeast Brazil. The four sampling areas included: (1) A native, preserved "caatinga" area with spine bearing trees and shrubs and some characteristic xerophytic plants (AN); (2) An area surrounding the mine, presenting the same type of vegetation although already degraded (AM); (3) A waste deposit area (AR); (4) Interface area between the waste deposit and a mining degraded area (AI). Samples were taken in each area $\left(1000 \mathrm{~m}^{2}\right)$ during two periods: wet $($ December $/ 2003$, Rainfall $=28.7 \mathrm{~mm})$ and dry $($ September $/ 2004$, Rainfall $=1.3 \mathrm{~mm})$. Results: Fluorescein diacetate hydrolysis values, microbial biomass $\mathrm{C}$ and basal respiration were higher in the preserved "caatinga" than in the impacted areas. The gypsum mining activity reduced the concentration of easily extractable glomalin in relation to the native "caatinga" area in both sampling periods. Higher deposits of total glomalin also occurred in the native area, however, mainly during the wet period. Conclusion: The mining activity produced a negative impact on the soil microbiota, reducing the total enzymatic activity. The microbial biomass was significantly lower in the waste deposit area than in the native and interface areas. The results indicated that the mining activity is harmful to the soil microbiota in this area and that glomalin can be a useful indicator of soil disturbance.
\end{abstract}

Key words: Glycoprotein, glomalin, microbial biomass, gypsum mining, AMF

\section{INTRODUCTION}

The municipality of Araripina is located in the State of Pernambuco, Northeast Brazil and occupies a total area of $1.914,4 \mathrm{~km}^{2}$ characterized by a semiarid climate and "caatinga" vegetation, with a number of trees and shrubs presenting many xerophytic characteristics. Araripina's main commodity is the gypsum industry; $40 \%$ of the world's crude gypsum is found in this area, making this region responsible for
95\% of the gypsum demand in the national market. Activities related to the extraction of gypsum have social and economical importance in this region, employing a large number of people. However, mining involves the removal of the vegetal cover and the soil organic layer, causing a severe environmental impact. Soil microbial activity is one of the key factors in ecosystem functioning (Ardakani et al., 2009). Thus, the evaluation of soil microbiological and biochemical attributes can be helpful in the identification of the

Corresponding Author: Adália Cavalcanti do Espírito Santo Mergulhão, Agronomic Institute of Pernambuco-IPA, Genomic Laboratory, General San Martin Avenue 1371 Bonji 50761-000, P. O. Box 1022,

Recife, PE, Brazil 
main limitations to impacted ecosystems and to suggest strategies aiming to maintain sustainability (Harris, 2003; Melloni et al., 2001).

Methods to estimate the microbial activity in semiarid soils are important for environmental monitoring and recovery of degraded areas (Pereira et al., 2004). Studies on the impact of environmental changes to microbial populations and their activity have used, among others: microbial biomass carbon, enzyme activity (fluorescein diacetate hydrolysis-FDA) and microbial respiration (Sarig and Steinberg, 1994; Garcia et al., 2004).

Microbial biomass can function as a reservoir of easily available nutrients or be catalyzed during the decomposition of organic matter (Garcia et al., 2004). Besides, working as an agent of biochemical transformation of organic compounds, microbes act as a reservoir of N, P and $\mathrm{S}$ in the soil (Wardle, 1992) and the evaluation of microbial biomass can supply useful data on changes in soil biological properties (Jordan et al., 1995). Microbial respiration is used as an indicator of soil quality in degraded areas. It is related to the loss of organic carbon from the plant-soil system to the atmosphere, nutrient cycling and response to soil management strategies (Parkin et al., 1997). The FDA hydrolysis is a measure for the evaluation of the impact of agricultural practices in the soil (Aon et al., 2001; Taylor et al., 2002) and can be affected by a variety of factors related to production, activity, catalytic behavior and persistence of enzymes in the soil (Gianfreda and Bollag, 1996; De Andrade and da Silveira, 2004).

Soil disturbance results in a decrease in microbial populations, among which the Arbuscular Mycorrhizal Fungi (AMF) are included, also affecting the vegetal community. The AMF are important components of sustainable systems as they improve the nutritional state of the associated photobiont (Mirzakhani et al., 2009) and soil structure via external mycelium and its byproducts, including glomalin. This relatively insoluble glycoprotein is related to soil aggregation due to its adhesive characteristics (Bird et al., 2002) and it is considered a large source of $\mathrm{C}$ in the soil (Rillig, 2004), contributing to better soil quality (Rillig et al., 2002). Organic $\mathrm{C}$ and $\mathrm{N}$ have been strongly correlated to glomalin-related soil proteins (Bird et al., 2002). Rillig et al. (2003) suggest that quantification of glomalin in the soil can be an important indicator of changes caused by soil disturbance and indicate soil reclamation. Glomalin has also been considered in biostabilization and remediation of polluted soils (Gonzalez-Chavez et al., 2004). Two main fractions of glomalin related soil proteins are usually considered is soil studies: the Easily Extractable (EEG) and the total (TG). The first includes the glomalin that is newly deposited by the AMF hyphae and is extracted after only one autoclave cycle in sodium citrate solution while the second represents the long term deposits and is extracted after a few more cycles. The effect of gypsum mining on production of glomalin related proteins is unknown. Therefore, this study represents the first attempt to determine the usefulness of this variable to detect changes produced by gypsum extraction.

The main objectives of this study are to evaluate and compare the biological state of soils from a preserved, native "caatinga" area and impacted gypsum mining areas. Moreover, the results can supply more evidence for recommendation of glomalin as a biochemical indicator of soil quality, considering that some glomalin fractions are potential indicators of the impact of agricultural practices, being identified as a biomarker for AMF biomass and activity in soil (Millner and Wright, 2002).

\section{MATERIALS AND METHODS}

A native preserved area and areas impacted by gypsum mining were selected at the Araripina Experimental Station (7³4'34' $S$ and 40'29'54' $\mathrm{W}$, $322 \mathrm{~m}$ height), located in the semiarid region of Pernambuco State, in Northeast Brazil. The four collecting areas included: (1) a native, preserved "caatinga" area (AN); (2) a caatinga degraded area surrounding the mine, with more sparse vegetation (AM); (3) a waste deposit area (AR); (4) interface between the waste deposit and a mining degraded area (AI). The "caatinga" is an exclusive Brazilian biome that covers more than $80000 \mathrm{~km}^{2}$, including all States of the Northeast region. It is characterized by a hot and dry climate and vegetation with trees and shrubs, many of them presenting spines and some xerophytic characteristics, belonging to Leguminosae, Apocynaceae, Euphorbiaceae, Cactaceae, Bromeliaceae and other families (Leal et al., 2003). Forty two plant species, belonging to 37 genera from 25 families are found in these areas; species of Leguminosae (Mimosoidae) and Euphorbiaceae are predominant, with six and four species, respectively (Mergulhao et al., 2007). Plant diversity is reduced in the impacted areas, with difference of up to $69 \%$ in comparison with the native area. The following species are present in the preserved area: Myracrodruon urundeuva Alemao and Spondias tuberosa Arruda (Anacardiaceae); Aspidosperma pyrifolium Mart. (Apocynaceae); Caparis hastata L. and Caparis flexuosa (L.) L. 
(Capparaceae); Parapiptadenia zehntneri (Harms) M.P. Lima, Mimosa tenuiflora (Willd.) Poir., $M$. ophthalmocentra Mart. Bemth. and Anadenanthera colubrina (Vell.) Brenan. (Fabaceae); Cissus simsiana Schult and Schult (Vitaceae). In the mining surroundings the vegetation is represented, among others, by Arrabidaea corallina (Jacq.) Sandw. (Bignoniaceae); Tagetes minuta L. (Asteraceae); Jatropha mollissima (Pohl.) Baill. (Euphorbiaceae); Cassia trachypus Mart ex Bemth. (Leguminosae Caesalpinoideae); Prosopis juliflora DC. (Fabaceae). In the interface between the preserved and the impacted areas there are some Cactaceae (Pilosocereus sp.), Euphorbiaceae (Croton sp. and Manihot sp.) and Fabaceae (Anadenanthera colubrina (Vell.) Brenan., P. juliflora). Only five species: Ruellia paniculata L., Alternanthera tenella Colla, Ziziphus joazeiro Mart., Croton sp. and the exotic P. juliflora are found in the most degraded area (deposit of mining waste). Roots obtained from the rhizosphere of the local plants were colonized by AMF. The degree of colonization varied between the areas: $37.5 \%$ in the preserved native area (AN), $42.5 \%$ in the mining degraded area (AI), 55\% in the surrounding area (AM) and $56.8 \%$ in the waste deposit area (AR) (Mergulhao et al., 2007).

Ten composite rhizosphere soil samples were collected $\left(5-20 \mathrm{~cm}\right.$ deep) in each area $\left(1000 \mathrm{~m}^{2}\right)$ during two periods: wet $($ December $/ 2003$, Rainfall $=28.7$ $\mathrm{mm})$ and dry (September/2004, Rainfall $=1.3 \mathrm{~mm})$. Part of the samples was taken to the Institute Agronomico of Pernambuco, for physical and chemical analysis (Table 1) and part was used for the other analysis.

Microbial biomass $\mathrm{C}$ was determined according to Vance et al. (1987): the soil extracts were filtered and maintained at $-4^{\circ} \mathrm{C}$. Later, the organic $\mathrm{C}$ was determined by the method of oxidation with potassium dichromate, after acid digestion at $100^{\circ} \mathrm{C}$ and titration with ammoniacal ferrous sulphate, using $\mathrm{Fe}$ as indicator. Basal respiration was determined in samples adjusted to $40 \%$ of field capacity, according to Grisi (1997), with the $\mathrm{CO}_{2}$ expressed in $\mu \mathrm{g}$ of $\mathrm{C} \mathrm{g}^{-1}$ of dry soil. Fluorescein Diacetate hydrolytical Activity (FDA) was estimated according to Swisher and Carroll (1980) and the results expressed in $\mu \mathrm{g}$ fluorescein $\mathrm{g}^{-1}$ of dry soil $\mathrm{h}^{-1}$. Two glomalin fractions-Easily Extractable (EEG) and Total (TG)-were quantified according to Wright and Upadhyaya (1998). To separate the aggregate fractions (1-2 mm), the soil was sieved (0.84 $\mathrm{mm}$ and $1.41 \mathrm{~mm}$ mesh sizes). For EEG, $2 \mathrm{~mL}$ of sodium citrate $(20 \mathrm{mM}$; $\mathrm{pH} 7.0)$ was added to $0.25 \mathrm{~g}$ of aggregates, followed by extraction in an autoclave $\left(121^{\circ} \mathrm{C} / 30 \mathrm{~min}\right)$ and further centrifugation $(1000 \mathrm{~g} / 5 \mathrm{~min})$.

Table 1: Chemical and physical characteristics of the soil collected in two periods (wet and dry), in four areas of a gypsum mining in Araripina, Pernambuco State, Brazil

\begin{tabular}{|c|c|c|c|c|c|c|c|c|c|c|c|c|}
\hline \multirow[b]{2}{*}{ Areas $^{1}$} & \multicolumn{3}{|c|}{$\mathrm{H}_{2} \mathrm{O} \mathrm{mg} \cdot \mathrm{dm}^{-3} \mathrm{~g} \cdot \mathrm{Kg}^{-1}$} & \multicolumn{3}{|c|}{ cmolc. $\mathrm{dm}^{-3}$} & \multicolumn{3}{|l|}{ meq. $\mathrm{L}^{-1}$} & \multicolumn{3}{|c|}{ Textural analysis (\%) } \\
\hline & $\mathrm{pH}$ & $\mathrm{P}$ & $\mathrm{C}$ & $\mathrm{Ca}$ & $\mathrm{Mg}$ & $\mathrm{K}$ & $\mathrm{SO}_{4}$ & $\mathrm{CO}_{3}$ & $\mathrm{HCO}_{3}$ & Sand & Clay & Silte \\
\hline \multicolumn{13}{|c|}{ Wet period } \\
\hline $\mathrm{AN}$ & 6.28 & 5 & 1.16 & 5.90 & 1.30 & 0.43 & Presence & 0.20 & 1.80 & 67 & 8 & 25 \\
\hline AI & 5.72 & 11 & 1.27 & 20.00 & 9.30 & 0.46 & Presence & 0.20 & 0.80 & 26 & 45 & 29 \\
\hline AM & 7.64 & 54 & 1.34 & 40.50 & 6.25 & 0.19 & Strong presence & 0.40 & 1.60 & 22 & 39 & 39 \\
\hline AR & 7.65 & 42 & 0.72 & 68.00 & 9.75 & 0.34 & Strong presence & 0.20 & 1.20 & 27 & 6 & 67 \\
\hline \multicolumn{13}{|c|}{ Dry period } \\
\hline $\mathrm{AN}$ & 6.43 & 8 & 1.20 & 6.20 & 1.15 & 0.36 & Presence & 0.80 & 5.60 & 74 & 8 & 18 \\
\hline AI & 5.72 & 14 & 1.30 & 36.25 & 11.25 & 0.62 & Strong presence & 0.00 & 0.80 & 14 & 59 & 27 \\
\hline AM & 7.52 & 161 & 1.33 & 45.40 & 3.10 & 0.40 & Strong presence & 0.00 & 1.60 & 22 & 47 & 31 \\
\hline $\mathrm{AR}$ & 7.56 & 32 & 0.65 & 61.75 & 1.65 & 0.46 & Strong presence & 0.20 & 2.40 & 37 & 28 & 35 \\
\hline Areas $^{1}$ & \multicolumn{2}{|c|}{$\mathrm{OM}(\%)$} & $\mathrm{Fe}\left(\mathrm{mg} \mathrm{dm}^{-3}\right)$ & & \multicolumn{2}{|c|}{ Dap $\left(\mathrm{g} \mathrm{cm}^{-3}\right)$} & $\operatorname{Dr}\left(\mathrm{g} \mathrm{cm}^{-3}\right)$ & $\mathrm{RH}(\%)$ & \multicolumn{2}{|c|}{ WP 15 Atm } & \multicolumn{2}{|c|}{ Textural class } \\
\hline \multicolumn{13}{|c|}{ Wet period } \\
\hline AN & \multicolumn{2}{|c|}{2.00} & 12.73 & \multicolumn{3}{|c|}{1.44} & 2.50 & 1.25 & \multicolumn{2}{|c|}{4.47} & \multicolumn{2}{|c|}{ Sandy Franco } \\
\hline AI & \multicolumn{2}{|c|}{2.19} & 52.50 & \multicolumn{3}{|c|}{1.21} & 2.55 & 6.90 & \multicolumn{2}{|c|}{20.51} & \multicolumn{2}{|l|}{ Clayey } \\
\hline AM & \multicolumn{2}{|c|}{2.31} & 0.93 & \multicolumn{3}{|c|}{1.20} & 2.31 & 8.65 & \multicolumn{2}{|c|}{24.88} & \multicolumn{2}{|c|}{ Clayey Franco } \\
\hline AR & \multicolumn{2}{|c|}{1.24} & 0.41 & \multicolumn{3}{|c|}{1.28} & 2.58 & 7.00 & \multicolumn{2}{|c|}{18.14} & \multicolumn{2}{|c|}{ Silty Franco } \\
\hline \multicolumn{13}{|c|}{ Dry period } \\
\hline $\mathrm{AN}$ & \multicolumn{2}{|c|}{2.07} & 13.73 & \multicolumn{3}{|c|}{1.34} & 2.59 & 0.40 & & & Sandy & anco \\
\hline AI & & & 79.80 & & 1.13 & & 2.44 & 8.60 & & & Clayey & \\
\hline AM & & & 0.71 & & 1.10 & & 2.36 & 6.80 & & & Clayey & ranco \\
\hline AR & & & 0.23 & & 1.22 & & 2.46 & 6.55 & & & Silty $\mathrm{F}$ & nco \\
\hline
\end{tabular}

${ }^{1}$ AN: Native, preserved "caatinga"; AM: Mine Surroundings; AR: Reject Area; AI: Interface between the waste deposit and an area of "caatinga" degraded by mining; OM: Organic Matter; Dap: Bulk density; Dr: Particle density; RH: Relative Humidity; WP: Welting point 
The TG fraction was extracted adding $2 \mathrm{~mL}$ of sodium citrate $(50 \mathrm{mM} ; \mathrm{pH} 8,0)$ to the sediment of the previous extraction of the EEG fraction, in eight cycles of extraction in an autoclave. At the end of each cycle, the material was centrifuged and the sediment resuspended with fresh $2 \mathrm{~mL}$ of the extracting solution. The supernatants from both fractions were stored $\left(-4^{\circ} \mathrm{C}\right)$ and the glomalin quantified using the Bradford total protein assay with bovine albumin as standard (Bradford, 1976).

Statistical design and analysis: The data were Analyzed using Variance Analysis (ANOVA) and the means compared by the Tukey test $(\mathrm{p}<0.05)$ using the Sanest program. Prior to analysis, microbial biomass was transformed into $\sqrt{ }(X)$, FDA and TG into $\sqrt{ }(X+0,5)$.

\section{RESULTS}

Microbial biomass $\mathrm{C}$ was lower in the impacted areas, with statistical difference observed only between the waste deposit area (AR) and the interface (AI) and native areas (AN) (Table 2). In general, fungal biomass was higher in soils of the native area where more plants are found; in this area $\mathrm{pH}$ was near neutrality (6.28-6.43 in wet and dry periods) and the levels of $\mathrm{P}, \mathrm{Ca}$ and $\mathrm{Mg}$ were lowers than in the other areas (Table 1). Soil samples from the preserved "caatinga" area had greater liberation of $\mathrm{C}-\mathrm{CO}_{2}$ per unit of time than those from the impacted areas (Table 2).

Total soil enzyme activity (i.e., FDA hydrolysis) was affected by the sampling period, with high values in the native and interface areas during the wet period, when compared to the dry period (Table 3 ). In the other areas the soil enzyme activity did not differ between periods. In general, the FDA hydrolysis, the $\mathrm{C}$ of microbial biomass and basal respiration were higher in the preserved, native "caatinga" area (AN) (Table 2 and 3).

The changes produced by the mining activity reduced the concentration of EEG in the affected areas in relation to the native "caatinga" in both sampling periods (Table 4). Higher EEG concentration was measured in the wet period in the native "caatinga" area, with the opposite occurring in the interface area (Table 4).

Table 2: Microbial biomass carbon and basal respiration in soil samples from a native and gypsum mining impacted areas, Araripina-PE, independent of sampling period

\begin{tabular}{|c|c|c|}
\hline Areas ${ }^{1}$ & 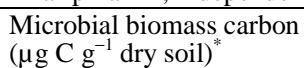 & $\begin{array}{l}\text { Basal respiration } \\
\left(\mu \mathrm{g} \mathrm{CO}_{2} \mathrm{~g}^{-1} \text { dry soil day }{ }^{-1}\right)^{* *}\end{array}$ \\
\hline$\overline{\mathrm{AN}}$ & $311.91 \mathrm{a}$ & $30.50 \mathrm{a}$ \\
\hline AI & $285.24 \mathrm{a}$ & $23.19 \mathrm{~b}$ \\
\hline $\mathrm{AM}$ & $226.28 \mathrm{ab}$ & $20.24 \mathrm{c}$ \\
\hline $\mathrm{AR}$ & $184.38 \mathrm{~b}$ & ${ }_{* *}^{17.82 \mathrm{c}}$ \\
\hline
\end{tabular}

In each column, letters compare each treatment. The means $(\mathrm{n}=5)$ followed by the same letter do not differ statistically $(\mathrm{p}<0.05)$ according to the Tukey test. Values changed $\sqrt{ }(X)$. ${ }^{1} A N=$ Native preserved area; $\mathrm{AM}=$ Area surrounding the mine; $\mathrm{AR}=$ Waste deposit area; AI = Interface between the waste deposit and a mining degraded area
For total glomalin (TG), there was an isolate effect of the factors (areas $\mathrm{p}<0.004$; sampling periods $\mathrm{p}<0.0001)$ without any interaction between each other. Higher total glomalin (TG) production occurred in the wet period compared to the dry period (3.4 and $2.8 \mathrm{mg}$ glomalin $\mathrm{g}^{-1}$ of soil aggregates, respectively) in the native area (Table 5). In the other areas, no significant differences in TG production were found between periods (Table 5).

Table 3: Fluorescein Diacetate hydrolysis Activity (FDA) in soil samples from a native and gypsum mining impacted areas, Araripina-PE

\begin{tabular}{llc}
\hline & $\mu \mathrm{g}$ FDA hydrolysis $\mathrm{g}^{-1}$ dry soil $^{-1}$ \\
\cline { 2 - 3 } Areas $^{1}$ & Wet period & Dry period \\
\hline AN & $39.96 \mathrm{aA}$ & $29.98 \mathrm{bA}$ \\
AI & $46.59 \mathrm{aA}$ & $7.01 \mathrm{bB}$ \\
AM & $26.34 \mathrm{aB}$ & $25.89 \mathrm{aA}$ \\
AR & $1.00 \mathrm{aC}$ & $1.00 \mathrm{aC}$
\end{tabular}

$\% \mathrm{CV}=12.93$

In each line, lower-case letters compare periods for each treatment and in each column, capital letters compare treatments within a period. The means (5 replicates) followed by the same letter do not differ statistically $(\mathrm{p}<0.05)$ from each other according to Tukey test. Values changes $\sqrt{ }(\mathrm{X}+0.5) .{ }^{1} \mathrm{AN}=$ Native preserved area; $\mathrm{AM}=$ Area surrounding the mine; $\mathrm{AR}=$ Waste deposit area; $\mathrm{AI}=$ Interface between the waste deposit and a mining degraded area

Table 4: Easily Extractable Glomalin (EEG) in soils from a native and degraded gypsum mining areas in Araripina-PE $\mathrm{mg}$ glomalin $\mathrm{g}^{-1} / 1-2 \mathrm{~mm}$ aggregates

\begin{tabular}{lll} 
Areas $^{1}$ & Wet period & Dry period \\
\hline AN & $1.21 \mathrm{aA}$ & $0.91 \mathrm{bA}$ \\
AI & $0.04 \mathrm{bB}$ & $0.44 \mathrm{aB}$ \\
$\mathrm{AM}$ & $0.01 \mathrm{aC}$ & $0.02 \mathrm{aB}$ \\
$\mathrm{AR}$ & $0.00 \mathrm{aC}$ & $0.01 \mathrm{aB}$ \\
$\% \mathrm{CV}=16.43$ & & \\
\hline
\end{tabular}

Capital letters compare among areas for each period and lower-case letters compare periods for each area. Means followed by the same letter do not differ statistically $(\mathrm{p}<0.05)$ according to the Tukey test. ${ }^{1} \mathrm{AN}=$ native preserved area; $\mathrm{AM}=$ area surrounding the mine; $\mathrm{AR}=$ waste deposit area; $\mathrm{AI}=$ interface between the waste deposit and a mining degraded area

Table 5: Total Glomalin (TG) in soils from a native and degraded gypsum mining areas in Araripina-PE, independent of harvest period

\begin{tabular}{ll}
\hline Areas $^{1}$ & $\begin{array}{l}\text { Total Glomalin (TG) } \\
\mathrm{mg} \text { glomalin } \mathrm{g}^{-1} / 1-2 \mathrm{~mm} \text { aggregates }\end{array}$ \\
\hline AN & $4.23 \mathrm{~A}$ \\
AI & $3.01 \mathrm{~B}$ \\
AM & $2.53 \mathrm{~B}$ \\
AR & $2.71 \mathrm{~B}$ \\
Wet period & $3.44 \mathrm{~A}$ \\
Dry period & $2.81 \mathrm{~B}$ \\
$\% \mathrm{CV}=10.69$ & \\
\hline
\end{tabular}

Means followed by the same letter do not differ $(\mathrm{p}<0.05)$ according to the Tukey test. Values changes $\sqrt{ }(\mathrm{X}+0.5) .{ }^{1} \mathrm{AN}=$ Native preserved area; $\mathrm{AM}=$ Area surrounding the mine; $\mathrm{AR}=$ Waste deposit area; $\mathrm{AI}$ $=$ Interface between the waste deposit and a mining degraded area 
Am. J. Agri. \& Biol. Sci., 5 (4): 422-429, 2010

\section{DISCUSSION}

The few differences on microbial biomass $\mathrm{C}$ among the areas might be related to the fact that total organic carbon and organic matter were similar between those areas, except for the deposit area (RA). The values for this variable (microbial biomass $\mathrm{C}$ ) are within the range mentioned for savannas, gallery forest and eucalyptus forest (Behera and Sahani, 2003; Melloni et al., 2001); but lower values were observed in other native semiarid area in Northeast Brazil (Pereira et al., 2004). Probably the gypsum mining activity contribute for increasing the levels of $\mathrm{pH}$ in the studied areas (almost neutral), reducing the metabolic activity of the microbial community. However, some AMF species, such as Glomus sp. and Paraglomus occultum support higher $\mathrm{pH}$, occurring in area with $\mathrm{pH}>7.0$ (Da Silva et al., 2005). Basal respiration is usually related to biomass $\mathrm{C}$ whether the community is metabolically inactive or in dormancy (Ohya et al., 1998). Soils impacted by anthropic action would be under stress, with less efficiency in the use of $\mathrm{C}$, resulting in high liberation of $\mathrm{CO}_{2}$ per unit of substrate (Insam et al., 1996). Changes in the respiratory activity due to the stress may also be related to alterations in the microbial biomass (Santruckova and StraSkraba, 1991). Soil samples from the preserved "caatinga" area had greater liberation of $\mathrm{C}-\mathrm{CO}_{2}$ per unit of time than those from the impacted areas indicating that the microbial community in this native area is more active than in the other areas. High microbial respiration indicates a more intense cycling of the microbial population, with consequent higher consumption of energy for survival (Behera and Sahani, 2003; Melloni et al., 2001). Confirming other studies, in some of the areas total soil enzyme was affected by the season, being higher during the wet than in the dry period. Conversely, greater enzyme activity (FDA) was found during the dry period in a semiarid soil cultivated with Atriplex nummularia (Pereira et al. 2004). Swisher and Carroll (1980) demonstrated that this variable (hydrolysis of FDA) is directly proportional to the microbial population. Probably the enzyme activity, the $\mathrm{C}$ of microbial biomass and basal respiration were higher in the preserved "caatinga" area due to a higher supply of organic matter for nutrient cycling in relation to the other areas especially that with mining waste. In native forest soils, losses of nutrients are smaller in relation to impacted ones, due to higher plant and microbial diversity, better soil cover throughout the year and higher immobilization in the soil (Behera and Sahani, 2003; Melloni et al., 2001).
As occurred with other variables, concentration of EEG was also lower in the mining affected areas, where in some samples it was not detected, in comparison with the preserved "caatinga". The EEG fraction may be an indicator of more recently deposited glomalin in the soil by AMF hyphae (Rillig, 2004). Other studies (Preger et al., 2007; Steinberg and Rillig, 2003) indicate that EEG and TG extraction protocols may not separate glomalin by age, as incubation studies have shown glomalin moving in and out of these pools over time. Detection of small amounts of glomalin in those impacted areas demonstrates the negative effect of the mining activity on the AMF and glomalin synthesis. High level of $\mathrm{Ca}$ and the strong presence of $\mathrm{SO}_{4}$ in the impacted areas may have contributed to the low production of EEG and TG. Levels of $\mathrm{P}, \mathrm{Ca}$ and $\mathrm{Mg}$ in the soil were negatively correlated with the production of glomalin (Lovelock et al., 2004). High level of Fe in the $\mathrm{AN}$ and AI areas indicates the importance of this element for glomalin production, considering that up to $8 \%$ of $\mathrm{Fe}$ is present in its structure (Wright and Upadhyaya, 1998).

Differences in the number of infective propagules and in number of AMF spores comparing dry and wet periods, as demonstrated in other "caatinga" areas (Souza et al., 2003), can contribute for changes in EEG concentration in the soil. In the native area, where the environmental conditions are more suitable, the wet period stimulates the growth of new roots resulting in greater proliferation of AMF and, as a consequence, higher concentrations of EEG are found in the soil. During the dry period, the AMF species present in the interface area, whose soil structure is compromised by the gypsum mining activity, can be dormant, increasing the number of propagules in the soil as a defense mechanism against adverse conditions; this would result in a decline of EEG in the soil. It has been suggested that the AMF can use two strategies (colonization and persistence) for surviving in an environment. In the first case, species more able to colonize new hosts are included and in the latter the species which remain in the system (soil/root) even under adverse conditions prevail (Hart et al., 2001).

The low TG measurements in the impacted areas suggest that the soil structure was compromised by the gypsum mining activity. Possibly, the extracted glomalin in these areas represents earlier deposits in the native area, as this glycoprotein can remain in the soil for many years (Rillig et al., 2001). The anthropic impact represented by the gypsum exploitation probably impaired the production of external mycelium, where glomalin is synthesized. In preserved areas $>60 \mathrm{mg}$ of total glomalin/g of soil can be extracted (Rillig et al., 
2001), while in our studies the values were comparatively smaller, especially in the degraded areas. However, glomalin production in the native area was higher than that measured in other semiarid soils (Bird et al., 2002). The high respiration rate and the highest easily concentrations of glomalin in the preserved "caatinga" area (AN) as observed in this study, may indicate a state of equilibrium in this ecosystem and the possibility that the aerobic heterotrophic microbiota is using the glycidic portion of this protein in their oxidative processes, as has been suggested (Harner et al., 2004).

\section{CONCLUSION}

Our data indicate that the environmental impact produced by the gypsum mining activity reduced the microbial biomass, the total enzymatic activity and production of glomalin in comparison to the native area (AN), where higher biological activity was detected. The possibility of using the easily extractable fraction of glomalin as an indicator of differences between soil treatments (a preserved "caatinga" versus areas impacted by gypsum mining) was confirmed. The results also showed that concentration of glomalin in the soil can be affected by wet or dry conditions. Further studies are needed to better clarify the role of the AMF in areas of gypsum extraction and the impact of this activity on soil quality.

\section{ACKNOWLEDGEMENT}

Thanks to the anonymous referees for the helpful suggestions. The authors also acknowledge the National Council for Scientific and Technological Development (CNPq) for financial support.

\section{REFERENCES}

Aon, M.A., M.N. Cabello, D.E. Sarena, A.C. Colaner and M.G. Franco et al., 2001. I-Spatio-temporal patterns of soil microbial and enzymatic activities in an agricultural soil. Applied Soil Ecol., 18: 239254. DOI: 10.1016/S0929-1393(01)00153-6

Ardakani, M.R., G. Pietsch, A. Moghaddam, A. Raza and J.K. Friedel, 2009. Response of root properties to tripartite simbiosis between lucerne (Medicago sativa L.), rhizobia and mycorrhiza under dry organic farming conditions. Am. J. Agric. Biol. Sci., $\quad$ 4: 266-277. http://www.scipub.org/fulltext/AJAB/AJAB44266277.pdf

Behera, N. and U. Sahani, 2003. Soil microbial biomass and activity in response to Eucalyotus plantation and natural regeneration on tropical soil. For. Ecol. Manage., 174: 1-11. DOI: 10.1016/S03781127(02)00057-9
Bird, S.B., J.E. Herrick, M.M. Wander and S.F. Wright, 2002. Spatial heterogeneity of aggregate stability and soil carbon in semi-arid rangeland. Environ. Pollut., 116: 445-455. DOI: 10.1016/S02697491(01)00222-6

Bradford, M.M., 1976. A rapid and sensitive method for the quantification of microgram quantities of protein utilizing the principle of protein-dye binding. Anal. Biochem., 72: 248-254. DOI: 10.1016/0003-2697(76)90527-3

Da Silva, A.G., S.F. Trufem, O.J. Saggin-Junior and L.C. Maia, 2005. Arbuscular mycorrhizal fungi in a semiarid copper mining area in Brazil. Mycorrhiza, 15: 47-53. PMID: 14767726

De Andrade, S.A.L and A.P.D. da Silveira, 2004. Soil microbial biomass and activity under the influence of lead addition and mycorrhizal soybean rhizosphere. Pesq. Agropec. Bras., 39: 1191-1198. DOI: 10.1590/S0100-204X2004001200005

Garcia, M.R.L., L.M.M. de Mello and A.M.R. Cassiolato, 2004. Microbial variables and productivity of bean under different soil managements and limestone application. Pesq. Agropec. Bras., 39: 1021-1026. DOI: 10.1590/S0100-204X2004001000010

Gianfreda, L. and J.M. Bollag, 1996. Influence of Natural and Anthropogenic Factors on Enzyme Activity in Soil. In: Soil Biochemistry, Stotzky, G. and J.M. Bollag (Eds.). Marcel Dekker, New York, ISBN: 0824785754, pp: 123-193.

Gonzalez-Chavez, M.C., R. Carrillo-Gonzalez, S.F. Wright and K.A. Nichols, 2004. The role of glomalin, a protein produced by arbuscular mycorrhizal fungi, in sequestering potentially toxic elements. Environ. Pollut., 130: 317-323. DOI: 10.1016/j.envpol.2004.01.004

Grisi, B.M., 1997. Temperature increase and its effect on microbial bi ass and activity of tropical and temperate soils. Rev. Microbiol., 28: 5-10. http://md1.csa.com/partners/viewrecord.php?reque ster $=$ gs \&collection $=E N V \&$ recid $=4112283 \& q$

Harris, J.A. 2003. Measurements of the soil microbial community for estimating the success of restoration. Eur. J. Soil Sci., 54: 801-808. DOI: 10.1046/j.1351-0754.2003.0559.x

Harner, M.J., P.W. Ramsey and M.C. Rillig, 2004. Protein accumulation and distribution in foodplain soils and river foam. Ecol. Lett., 7: 829-836. DOI: 10.1111/j.1461-0248.2004.00638.x

Hart, M.M., R.J. Reader and J.N. Klironomos, 2001. Life-history strategies of arbuscular mycorrhizal fungi in relation to their successional dynamics. Mycologia, 93: 1186-1194. http://www.jstor.org/stable/3761678 
Insam, H., T.C. Hutchinson and H.H. Reber, 1996. Effects of heavy metal stress on the metabolic quotient of the soil microflora. Soil Biol. Biochem., 28: 691-694. DOI: 10.1016/0038-0717(95)00182-4

Jordan, D., R.J. Kremer, W.A. Bergfield, K.Y. Kim and V.N. Cacnio, 1995. Evaluation of microbial methods as potential indicators of soil quality in historical agricultural fields. Biol. Fertility Soils, 19: 297-302. DOI: 10.1007/BF00336098

Leal, I.R., M. Tabarelli and J.M.C. da Silva, 2003. Caatinga Conservation and Ecology. 1st Edn., Universidade Federal de Pernambuco, Recife, ISBN: 857315215x, pp: 804.

Lovelock, C.E., S.F. Wright and K.A. Nichols, 2004. Using glomalin as an indicator for arbuscular mycorrhizal hyphae growth: An example from a tropical rain forest soil. Soil Biol. Biochem., 36: 1009-1012. DOI: 10.1016/j.soilbio.2004.02.010

Melloni, R., E.G. Pereira, I.C.B. Trannin, D.R. Santos and F.M.S. Moreira et al., 2001. Biological characteristics of soils under riparian woodland and grassland in southern Minas Gerais State. Cienc. Agrotec., 25: 7-13. http://www.editora.ufla.br/site/_adm/upload/revista 125-1-2001_01.pdf

Mergulhao, A.C.E.S., J.P. Oliveira, H.A. Burity and L.C. Maia, 2007. Infectivity potential of arbuscular mycorrhizal fungi in native and impacted gypsum mining areas of the Brazilian semiarid. Hoehnea, 34: 341-348.

Millner, P.D. and S.F. Wright, 2002. Tools for support of ecological research on arbuscular mycorrhizal fungi. Symbiosis, 33: 101-123. http://cat.inist.fr/?aModele=afficheN\&cpsidt=14353175

Mirzakhani, M. M.R. Ardakani, A.A. Band, F. Rejali and A.H.S. Rad, 2009. Response of spring safflower to co-inoculation with Azotobacter chroococum and Glomus intraradices under different levels of nitrogen and phosphorus. Am. J. Agric. Biol. Sci., 4: 255-261. http://www.scipub.org/fulltext/AJAB/AJAB43255261.pdf

Ohya, H., S. Fujiwara, Y. Komai and M. Yamaguchi, 1998. Microbial biomass and activity in urban soils contaminated with $\mathrm{Zn}$ and $\mathrm{Pb}$. Biol. Fertility Soils, 6: 9-13. DOI: 10.1007/BF00257913

Parkin, T.B., J.W. Doran and E. Franco-Vizcaino, 1997. Field and Laboratory Tests of Soil Respiration. In: Methods for Assessing Soil Quality, Doran, J.W. and A.J. Jones (Eds.). Soil Science Society of America, Madison, Wisconsin, ISBN: 10: 0891188266, pp: 231-245.
Pereira, S.V., C.R. Martinez, E.R. Porto, B.R.B. Oliveira and L.C. Maia, 2004. Microbial activity in a semiarid soil cultivated with Atriplex nummularia. Pesq. Agropec. Bras., 39: 757-762. DOI: 10.1590/S0100-204X2004000800005

Preger, A.C., M.C. Rillig, A.R. Johns, C.C. Du Preez and I. Lobe et al., 2007. Losses of glomalin-related soil protein under prolonged arable cropping: A chronosequence study in sandy soils of the South African Highveld. Soil Biol. Biochem., 39: 445-453. DOI: 10.1016/j.soilbio.2006.08.014

Rillig, M.C., 2004. Arbuscular mycorrhizae, glomalin and soil aggregation. Can. J. Soil Sci., 84: 355-363. http://dbs.umt.edu/research_labs/rilliglab/Rillig\%2 02004\%20Can\%20J\%20S\%20Sc.pdf

Rillig, M.C., P.W. Ramsey, S. Morris and E.A. Paul, 2003. Glomalin, an arbuscular-mycorrhizal fungal soil protein, responds to land-use change. Plant Soil, 253: 293-299. DOI: 10.1023/A:1024807820579

Rillig, M.C., S.F. Wright and V.T. Eviner, 2002. The role of arbuscular mycorrhizal fungi and glomalin in soil aggregation: Comparing effects of five plant species. Plant Soil, 238: 325-333. DOI: 10.1023/A:1014483303813

Rillig, M.C., S.F. Wright, K.A. Nichols, W.F. Schmidt and M.S. Torn, 2001. Large contribution of arbuscular mycorrhizal fungi to soil carbon pools in tropical forest soils. Plant Soil, 233: 167-177. DOI: $10.1023 / \mathrm{A}: 1010364221169$

Santruckova, H. and M. StraSkroba, 1991. On the relationship between specific respiration activity and microbial biomass in soils. Soil Biol. Biochem., 23: 525-532. DOI: 10.1016/00380717(91)90109-W

Sarig, S. and Y. Steinberger, 1994. Microbial biomass response to seasonal fluctuation in soil salinity under the capony of desert halophytes. Soil Biol. Biochem., 26: 1405-1408. DOI: 10.1016/00380717(94)90224-0

Souza, R.G., L.C. Maia, M.F. Sales and S.F.B. Trufem, 2003. Diversity and infectivity potential of arbuscular mycorrhizal fungi in an area of "caatinga" in the Xingó Region, State of Alagoas, Brazil. Rev. Bras. Bot., 26: 49-60. DOI: 10.1590/S0100-84042003000100006

Steinberg, P.D. and M.C. Rillig, 2003. Differential decomposition of arhuscular mycorrhizal fungal hyphae and glomalin. Soil Biol. Biochem., 35: 191-194. DOI: 10.1016/S0038-0717(02)00249-3 
Swisher, R. and G.C. Carroll, 1980. Fluorescein diacetate hydrolisis as an estimator of microbial biomass on coniferous needle surfaces. Microbiol. Ecol., 6: 217-226. DOI: 10.1007/BF02010387

Taylor, J.P., B. Wilson, M.S. Mills and R.G. Burns, 2002. Comparison of microbial numbers and enzymatic activities in surface soils and subsoils using various techniques. Soil Biol. Biochem., 34: 387-401. DOI: 10.1016/S0038-0717(01)00199-7

Vance, E.D., P.C. Brookes and D.S. Jenkinson, 1987. An extraction method for measuring soil microbial biomass C. Soil Biol. Biochem., 19: 703-707. DOI: 10.1016/0038-0717(87)90052-6
Wardle, D.A., 1992. A comparative assessment of factors which influence microbial biomass carbon and nitrogen levels in soil. Biol. Rev., 67: 321-358. DOI: 10.1111/j.1469-185X.1992.tb00728.x

Wright, S.F. and A. Upadhyaya, 1998. A survey of soils for aggregate stability and glomalin, a glycoprotein produced by hyphae of arbuscular mycorrhizal fungi. Plant Soil, 198: 97-107. DOI: 10.1023/A:1004347701584 